been raised from $£ 1$ to $£ 110 s$. for those who elect to receive the Transactions. The president for the coming year is Mr. William M. Vermilye, of the National City Bank, New York, who has been treasurer of the American branch for some time. In spite of the difficulties due to the War, a good programme was carried through, and the report contains the titles of seventeen papers and addresses which will ultimately be published in vol. 23 of the. Trans. actions. Vol. 21 is in the press and it is hoped will be issued shortly. At the close of the business, special reference was made to the unceasing efforts on behalf of the Society of Dr. H. W. Dickinson. After the business was concluded Mr. R. P. Howgrave-Graham gave a lecture on "Engineering in Early Warfare", the devices of centuries ago being illustrated from documents and pictures.

\section{A New Source of Vitamin C}

THe Biochemical Bulletin, No. 27, May 1943, published by the Sino-British Co-operation Office, includes among other items of interest an article by T. M. Chen, S. Ho, K. M. Hsieh and T. Shen on "A Very Rich Souree of Vitamin C : the Wild Fruit of Emblio from India and S. China". It was thought that this wild fruit might be used as a cheap and convenient source of vitamin $\mathrm{C}$ for the Allied Armies in this theatre of war. The tree, Phyllanthus Emblica L., bears the fruit, which is "fleshly, depressed, globose, 3 in.-1 in. diameter, obscurely 6-lobed". The juice is very sour and astringent but contains about ten times as much ascorbic acid by indophenol titration as lemon juice, an average figure of $921 \mathrm{mgm} . /$ $100 \mathrm{ml}$. juice being given. This is qualitatively supported by guinea pig tests. It is not toxic for humans, who probably utilize it to the same extent as the crystalline vitamin.

\section{Miners' Welfare National Scholarships}

The trustees of the Miners'. Welfare National Scholarship Scheme invite applications for a limited number of university scholarships for award in 1944; there are, in addition, a limited number of exhibitions available for award to the most meritorious of the unsuccessful candidates for scholarships. Candidates must be either workers in or about coal mines in Great Britain, or sons or daughters of such workers, and should not normally be less than seventeen years of age on January 25, 1944. Forms of application and full particulars may be obtained from the Secretary, Miners' Welfare National Scholarship Scheme, Ashley Court, Ashtead, Surrey. Applicants for forms must state whether they apply as workers in or about mines or as children of such workers ; those who come within both categories should apply as miners. Applicants already at a university should state, when applying for forms, whether they are first-year students. Application forms must be returned by January 25 .

\section{Comet Daimaca}

I.A.U. Circular No, 965 announces that an orbit has been computed for this comet by Mr. Naur from three observations at the Observatory of Bucharest on September 9, 10 and 11. The elements of the orbit are given below.

$$
\left.\begin{array}{lcc}
T & 1943 & \text { Aug; } \\
w & 36^{\circ} & 02 \cdot 0^{\prime} \\
\Omega & 82 & 15 \cdot 1 \\
i & 161 & 15 \cdot 7
\end{array}\right\} 1948 \text { U.T. }
$$

From these elements the following ephemeris has been computed. As the orbit has been derived from short ares, the figures given below cannot be accepted as very accurate. The comet was stated to be mag. 10 on September 18, when its distances from the earth and sun were 0.32 and 0.92 , respectively. As it has receded considerably from the earth and sun since that date, it must be a faint object now, probably about mag. 16.

\begin{tabular}{|c|c|c|c|c|}
\hline \multicolumn{5}{|c|}{ Ephemeris } \\
\hline $\begin{array}{c}\text { Date } 1943 \\
\text { Nov. } 16 \\
20 \\
24 \\
28\end{array}$ & $\begin{array}{rr}r . & m . \\
18 & 48 \cdot 2 \\
18 & 51 \cdot 5 \\
18 & 54 \cdot 6 \\
18 & 58 \cdot 0\end{array}$ & \begin{tabular}{ll}
\multicolumn{2}{c}{ Dec. } \\
$11^{\circ}$ & $56^{\prime}$ \\
12 & 25 \\
12 & 49 \\
13 & 10
\end{tabular} & $\begin{array}{c}\rho \\
2 \cdot 107 \\
2 \cdot 229 \\
2 \cdot 342 \\
2 \cdot 459\end{array}$ & $\begin{array}{c}r \\
1 \cdot 658 \\
1 \cdot 713 \\
1 \cdot 764 \\
1 \cdot 823\end{array}$ \\
\hline
\end{tabular}

\section{Announcements}

Prof. A. V. Hill, secretary of the Royal Society, is to visit India to advise on problems of scientific and industrial research in relation to reconstruction problems and the co-ordination of such research in India with that elsewhere. His tour is being undertaken at the invitation of the Government of India and with the consent of the Royal Society.

SorENTIFIC men and many others will learn with muoh pleasure that Prof. Niels Bohr, of the Institute of Theoretical Physics, Copenhagen, has succeeded in escaping from Denmark and has reached Great Britain.

ThE Council of the Royal Meteorological Society has awarded the Symons Gold Medal for 1944 to Dr. C. W. B. Normand, director-general of observatories in India. The medal is awarded biennially for distinguished work in connexion with meteorological science.

Sir George Thomson, professor of physics at the Imperial College of Science and Technology, London, has been appointed scientific adviser to the Air Ministry. He will be responsible for examining air operations from the scientific aspect, the methods, weapons and equipment employed, and for advising the Air Staff and other Air Ministry departments on these matters. On all questions affecting radiocommunication and radiolocation Sir George Thomson will work in consultation with Sir Rokert WatsonWatt, scientific adviser on telecommunications.

Mr. George Hurst has been appointed lecturer in mining and mine surveying in the University of Sheifield. The Rockefeller Foundation has renewed its grant to the University of Sheifield of $£ 400$ for research in biochemistry for a further year beginning October 1, 1943.

The Huxley Memorial Lecture of the Royal Anthropological Institute will be delivered by Prof. F. C. Bartlett, professor of experimental psychology in the University of Cambridge, in the rooms of the Royal Society on November 23; he will speak on "Anthropology in Reconstruction".

The Spanish Cultural Institute at Buenos Aires has recently dedicated a histological laboratory to the memory of Ramon y Cajal; it is under the direction of Prof. Hortegan, one of his pupils.

Erratum. In Nature of November 6, p. 540, ool. 2 , in the communication signed by Prof. E. F. Burton, the size of the fibre used is given as "approximately $0.7 \mathrm{~m} \mu$ in diameter"; this should be " $0.7 \mu$ ". 